\title{
Dust Explosion Prevention and Mitigation, Status and Developments in Basic Knowledge and in Practical Application
}

\author{
Rolf K. Eckhoff ${ }^{1,2}$ \\ ${ }^{1}$ Department of Physics and Technology, University of Bergen, Allegaten 55, N-5007 Bergen, Norway \\ ${ }^{2}$ Tyréns AB, 20519 Malmö, Sweden \\ Correspondence should be addressed to Rolf K. Eckhoff, rolf.eckhoff@ift.uib.no
}

Received 23 January 2009; Accepted 23 March 2009

Recommended by Mostafa Barigou

Right from the early days of the process industries, continuous efforts have been made to develop and improve measures for prevention and mitigation of dust explosions in these industries. Nevertheless this hazard continues to threaten industries that manufacture, use and/or handle powders and dusts of a wide range of combustible materials. To improve methods for predicting explosion development in real industrial plant has been one major challenge. Hence, during the last years comprehensive numerical simulation codes, for addressing this problem, have been developed. Progress has also been made in other areas, for example, ignition source prevention. The importance of adopting inherently safer process design, by building on firm knowledge in powder science and technology, and of systematic education/training of personnel, is also emphasized.

Copyright ( 2009 Rolf K. Eckhoff. This is an open access article distributed under the Creative Commons Attribution License, which permits unrestricted use, distribution, and reproduction in any medium, provided the original work is properly cited.

\section{Introduction}

Table 1 gives an overview of the most important methods currently used for preventing and mitigating dust explosions in the process industries. In dust explosion prevention and mitigation, as in many other challenges encountered by the process industries, there is an inevitable conflict between the short-term needs of the users of knowledge and technology and the long-term strive by researchers for the "perfect" solution. Industry will always need practicable tools and means that can be implemented more or less immediately. On the other hand, however, industrial pragmatism must not block the constant strive for better solutions based on improved basic understanding of the phenomena involved. A main aim of the present paper is to elucidate how fundamental research can promote further development of the practical means for preventing and mitigating dust explosions in industry that are listed in Table 1.

\section{In-Depth Knowledge - a Powerful and Essential Tool in Assessing and Controlling Dust Explosion Hazards in Practice}

Over the last 20 years, there has been a gradual shift in approach in dust explosion prevention and mitigation, from simple schematic design methods, toward more sophisticated ones opening up for increased flexibility and tailoring. During the same time period the appreciation of the benefits to be harvested from cross-fertilization between systematic research and practical applications has been growing. Advanced numerical models are starting to play an increasingly important role in solving practical design problems. The development of such models requires detailed experimental and theoretical studies of the relevant physical and chemical aspects. Table 2 summarizes some fundamental research topics that are essential for further development of the preventive and mitigatory methods and design tools, that are indicated in Table 1. For example, basic understanding of flame propagation processes in dust clouds is the key to adequate design of practical mitigatory measures such as systems for dust explosion venting, suppression, and isolation. In Section 3 some work on basic aspects of dust flames will be reviewed.

\section{Flame Propagation in Dust Clouds}

3.1. Differences between Premixed Gases and Dust Clouds. In dust clouds, as opposed to premixed gases, inertial forces can produce fuel concentration gradients (displacement of particles in relation to gas phase). Furthermore, thermal 
TABLE 1: Schematic overview of means of preventing and mitigating dust explosions.

\begin{tabular}{|c|c|c|}
\hline \multicolumn{2}{|c|}{ Explosion prevention } & \multirow{2}{*}{ Explosion mitigation } \\
\hline $\begin{array}{l}\text { Preventing explosive dust } \\
\text { clouds }\end{array}$ & Preventing ignition sources & \\
\hline $\begin{array}{l}\text { Inerting of dust clouds by } \\
\mathrm{N}_{2}, \mathrm{CO}_{2} \text { and rare gases }\end{array}$ & $\begin{array}{l}\text { Smouldering combustion } \\
\text { in dust, dust fires }\end{array}$ & $\begin{array}{l}\text { Explosion-pressure } \\
\text { resistant construction }\end{array}$ \\
\hline $\begin{array}{l}\text { Intrinsic inerting of dust } \\
\text { cloud by combustion gases }\end{array}$ & $\begin{array}{l}\text { Other types of open flames } \\
\text { (e.g., hot work) }\end{array}$ & $\begin{array}{l}\text { Explosion isolation } \\
\text { (sectioning) }\end{array}$ \\
\hline $\begin{array}{l}\text { Inerting of dust cloud by } \\
\text { adding inert dust }\end{array}$ & $\begin{array}{l}\text { Hot surfaces (electrically or } \\
\text { mechanically heated) }\end{array}$ & Explosion venting \\
\hline $\begin{array}{l}\text { Keeping dust conc. outside } \\
\text { explosive range }\end{array}$ & $\begin{array}{l}\text { Heat from mechanical } \\
\text { impact (metal sparks and } \\
\text { hot-spots) }\end{array}$ & $\begin{array}{l}\text { Automatic explosion } \\
\text { suppression }\end{array}$ \\
\hline \multirow[t]{2}{*}{$\begin{array}{l}\text { Inherently safer process } \\
\text { design }\end{array}$} & $\begin{array}{l}\text { Electric sparks and arcs and } \\
\text { electrostatic discharges }\end{array}$ & $\begin{array}{l}\text { Partial inerting of dust } \\
\text { cloud by inert gas }\end{array}$ \\
\hline & & $\begin{array}{l}\text { Good housekeeping (dust } \\
\text { removal/cleaning) }\end{array}$ \\
\hline
\end{tabular}

TABLE 2: Fundamental aspects addressed in dust explosion research.

\begin{tabular}{|c|c|c|c|}
\hline $\begin{array}{l}\text { Dust cloud formation } \\
\text { processes }\end{array}$ & $\begin{array}{l}\text { Dust cloud ignition } \\
\text { processes }\end{array}$ & $\begin{array}{l}\text { Flame propagation } \\
\text { processes in dust clouds }\end{array}$ & $\begin{array}{l}\text { Blast waves generated by } \\
\text { burning dust clouds }\end{array}$ \\
\hline $\begin{array}{l}\text { Inter-particle forces in dust } \\
\text { deposits (cohesion) }\end{array}$ & $\begin{array}{l}\text { General theories for } \\
\text { ignition of single particles } \\
\text { and clouds }\end{array}$ & $\begin{array}{l}\text { Single-particle ignition and } \\
\text { combustion in hot oxidizer } \\
\text { gas }\end{array}$ & $\begin{array}{l}\text { Blast wave properties as a } \\
\text { function of properties of } \\
\text { burning dust clouds }\end{array}$ \\
\hline $\begin{array}{l}\text { Entrainment of particles } \\
\text { from dust deposits by } \\
\text { shock waves passing across } \\
\text { the deposit surface }\end{array}$ & $\begin{array}{l}\text { Ignition by smouldering } \\
\text { combustion in dust } \\
\text { layers/deposits } \\
\text { Ignition by hot surfaces }\end{array}$ & $\begin{array}{l}\text { Laminar and turbulent } \\
\text { flames in dust clouds }\end{array}$ & $\begin{array}{l}\text { Effects of blast waves on } \\
\text { humans and mechanical } \\
\text { structures }\end{array}$ \\
\hline $\begin{array}{l}\text { Entrainment of particles } \\
\text { from dust deposits by } \\
\text { turbulent gas flows }\end{array}$ & $\begin{array}{l}\text { Ignition by flying burning } \\
\text { metal particles }\end{array}$ & $\begin{array}{l}\text { Mechanisms of heat } \\
\text { transfer (conduction, } \\
\text { convection, radiation) }\end{array}$ & $\begin{array}{l}\text { Ability of blast waves from } \\
\text { dust explosions to } \\
\text { transform dust layers into } \\
\text { explosive dust clouds } \\
\text { (coupled to first column of } \\
\text { table) }\end{array}$ \\
\hline \multirow[t]{4}{*}{$\begin{array}{l}\text { Transport of dust particles } \\
\text { in turbulent gas flows }\end{array}$} & $\begin{array}{l}\text { Ignition by electric sparks } \\
\text { and arcs }\end{array}$ & & \\
\hline & $\begin{array}{l}\text { Ignition by electrostatic } \\
\text { discharges }\end{array}$ & \multirow{3}{*}{$\begin{array}{l}\text { Limit conditions for flame } \\
\text { propagation in dust clouds } \\
\text { (particle properties, dust } \\
\text { conc., oxygen conc., } \\
\text { geometry). }\end{array}$} & \\
\hline & Ignition by hot gas jets & & \\
\hline & Ignition by shock waves & & \\
\hline $\begin{array}{l}\text { Measurement and } \\
\text { characterization of } \\
\text { turbulence in dust clouds }\end{array}$ & $\begin{array}{l}\text { Ignition by hot-spots from } \\
\text { focused light beams }\end{array}$ & $\begin{array}{l}\text { Acceleration of flames in } \\
\text { dust clouds by turbulence } \\
\text { mechanisms }\end{array}$ & \\
\hline $\begin{array}{l}\text { Measurement and } \\
\text { characterization of spatial } \\
\text { distribution of particles in } \\
\text { dust clouds }\end{array}$ & $\begin{array}{l}\text { Influences on dust cloud } \\
\text { ignition sensitivity of cloud } \\
\text { properties (composition, } \\
\text { size, shape of particles, dust } \\
\text { concentration, } \\
\text { composition, turbulence, } \\
\text { temperature and pressure } \\
\text { of gas phase) }\end{array}$ & $\begin{array}{l}\text { Detonation phenomena in } \\
\text { dust clouds }\end{array}$ & \\
\hline
\end{tabular}


radiation may contribute significantly to the heat transfer from the flame to the unburnt cloud, depending on the type of particle material (e.g., light metals). More work is needed to explore the role of thermal radiation in the development and course of dust explosions. Some papers discussing various central issues are those by Lee et al. [1] and Wolanski [2]. Much research work has been done on various aspects of combustion of liquid sprays and mists [3], which is in part also relevant even in the context of dust explosions.

3.2. Ignition and Combustion of Single Particles. Through the years a substantial amount of work has been conducted on various aspects of the ignition and combustion of single particles. A comprehensive review is given by Eckhoff [4]. Two more recent examples will be given here. One is the general study by Frolov et al. [5] on the effect of transient heat transfer on ignition of solid particles; the other is the investigation by Fedorov and Shulgin [6] on the stability of the process of ignition of small magnesium particles.

3.3. Flames in Dust Clouds. It has often been assumed that the laminar burning velocity of a given dust cloud is a basic combustion property of the cloud, which is closely related also to the burning velocities at various defined levels of turbulence and hence to the flame propagation through that type of cloud at large. An excellent recent contribution to improve understanding of the nature of laminar dust flames was given by Dahoe et al. [7].

Adequate submodels of flame propagation in turbulent dust clouds are essential in comprehensive numerical codes for dust explosion propagation.

In the case of gases, extensive experimental research programmes have been conducted to resolve basic flame acceleration mechanisms in obstructed geometries. Central contributors are Moen et al. [8], Hjertager et al. [9], and Bakke and van Wingerden [10]. The fundamental studies of Rzal-Rebière and Veyssière [11] provide significant insight in possible differences between turbulent combustion of premixed gases and dust clouds. They investigated the interaction of a laminar maize starch/air flame with an obstacle, namely, a sphere, a disk, or an annulus.

One very interesting possibility would be to perform dust explosion experiments in large-scale experimental facilities used in previous extensive gas explosion experiments, for example, in the experiments by Moen et al. [8] on the influence of turbulence-generating baffles. By repeating these experiments with explosive dust clouds, and comparing the results with those found previously for gas, both important similarities and important discrepancies between turbulent dust and gas explosions could be disclosed.

Significant differences between combustion of premixed gases and dust clouds also exist on the microscopic scale. For example, the basic microscopic turbulence mechanisms that promote the combustion process must be identified. The results of Mitgau [12] and Mitgau et al. [13] indicate that more efficient replacement of gaseous reaction products by fresh air round each particle can be a strong basic turbulent combustion enhancement mechanism.
Cashdollar and Zlochower [14] measured flame temperatures and maximum explosions pressures in dust explosions with powders of a wide range of metals and sulphur, boron, and carbon. These data are useful in developing numerical models of dust flames.

3.4. Comprehensive Mathematical Models for Turbulent Flame Propagation in Dust Clouds. Kjäldman [15] was one of the pioneers in applying computational fluid dynamics (CFD) to turbulent dust explosion propagation. Subsequent contributions were made by Rose et al. [16], Smirnov et al. [17], Bielert and Sichel [18], Wörsdörfer et al. [19], Korobeinikov et al. [20], Zhong et al. [21], and Kosinski et al. [22]. Di Benedetto and Russo [23] presented a thermokinetic model of dust explosion propagation for natural and synthetic organic dusts. The model was based on the assumption that the devolatilization/pyrolysis step is very fast, and that the subsequent gas phase explosion is controlling the explosion rate. In developing a comprehensive numerical code for dust explosion simulation, corresponding existing codes for gas explosion simulation constitute a logical starting point. The comprehensive FLame ACceleration Simulator (FLACS) code, originally developed by Hjertager et al. [9] is currently being used as a basis for developing the corresponding dust explosion code Dust Explosion Simulation Code (DESC). van Wingerden et al. [24], Arntzen et al. [25], Hansen et al. [26], and Siwek et al. [27] presented dust explosion simulations using preliminary versions of the DESC code. Skjold et al. [28-33] and Skjold [34], using improved versions of the same code, presented results from extensive simulations of dust explosion experiments performed in full scale process equipment, including a silo of $236 \mathrm{~m}^{3}$.

Most probably this type of comprehensive numerical computer simulation code will become a future tool for predicting the course of complex dust explosion scenarios encountered in the process industries, for example, explosions propagating through a series of consecutive process units connected with ducts.

\section{Generation of Explosive Dust Clouds in Process Plant and Means for Their Prevention}

4.1. A Historical Perspective. Nearly 130 years ago Professor Weber, one of the pioneers of dust explosion research, stressed the importance of accounting for dust cohesion and dust dispersibility when considering the possibility of generation of explosive dust clouds. In his excellent paper on the ignitability and explosibility of wheat flour, Weber [35] emphasized that the cohesion of the flour, which is caused by interparticle adhesion, has a strong influence on the ability of the flour to disperse into explosive dust clouds. Weber suggested that two large dust explosion disasters, one in Szczecin (Stettin) and one in München, were mainly due to the high dispersibility of the flour. He also demonstrated, using simple but convincing laboratory experiments, that the dispersibility, or dustability, of wheat flour increased as its moisture content decreased. A global definition of dust dispersibility is given in Eckhoff [4, Chapter 3]. 
4.2. Generation of Primary Dust Clouds Inside Process Equipment. In order for an explosive dust cloud to be formed from a layer/deposit, the layer/deposit must be exposed to a process that suspends the particles in the air to the extent that the dust concentration drops into the explosive range. Most often such dispersion of dust to form explosive clouds takes place intentionally inside process equipment, for example, by handling and transportation in various process equipment (e.g., mills, dryers, mixers, bucket elevators and other conveyors, silos, filters, cyclones, and connecting ducts). It is foreseen that in a not-too-distant future comprehensive numerical codes will be available for predicting the dust cloud structures (spatial distributions of effective particle size, dust concentration, turbulence, and global flow) that will be generated in various practical scenarios in industry. Knowing this initial cloud structure is essential both for predicting the ignition sensitivity of the cloud with regard to various ignition sources and for predicting the course of development of the primary explosion that will result from ignition. Therefore, adequate information about initial dust cloud structures is essential for realistic assessment of the dust explosion risk in a process plant. However, the development of adequate numerical models of dust cloud structures is not far beyond its infancy, and information of practical use is scarce. The works of Hauert et al. [36] and Kosinski et al. [37] constitute valuable initial contributions. More recent contributions are by Kosinski and Hoffmann [38], Kosinski et al. [39], and Ilea et al. [40]. However, the problem addressed is very complex and more experimental, and theoretical work is needed.

4.3. Generation of Secondary Dust Clouds Inside and/or Outside Process Equipment by Blast Waves from Primary Dust Explosions. The blast wave from a primary dust explosion can generate secondary explosive clouds ahead of the flame by entraining dust deposits and layers there. Lebecki et al. [41], being primarily concerned with coal mine explosions, investigated this process experimentally in a $100 \mathrm{~m}$ long gallery of cross-section $3 \mathrm{~m}^{2}$. Kauffman et al. [42] and Austin et al. [43] summarized their extensive research on blast-wave entrainment of dust layers in long tubes, whereas Boiko and Poplavski [44] studied the effect of the dust concentration in a dust cloud behind a shock wave, on the acceleration of the cloud. Data from this kind of work are essential in the development of comprehensive dust explosion codes. Klemens et al. [45] presented a mathematical model for simulating the process of entrainment of dust particles from a dust layer, by the gas flow behind a shock or a rarefaction wave passing across the layer. The above mentioned subsequent contributions by Kosinski and Hoffmann [38], Kosinski et al. [39], and Ilea et al. [40] are indeed relevant also in the present context. The mathematical models of Fedorov and Gosteev [46] and Fedorov and Fedorova [47] describing the initial stage of the entrainment of single dust particles from a dust layer by a gas flow passing across the layer are also important contributions.

4.4. Dust Dispersibility Tests. Various test methods have been proposed for evaluating the ease with which dust clouds can be produced from deposits and layers of powders/dusts [4, Chapter 7], [48-51].

4.5. Inherently Safer Process Design to Prevent/Limit Generation of Explosive Dust Clouds. Most commonly the dust explosion hazard is combated by adding preventive and mitigatory measures to an existing process. However, the technical measures adopted are often expensive, and safety procedures may fail.

Inherent safety is an alternative approach. It implies that the process itself be designed in such a way that no explosion hazard exists. Kletz [52], the "father" of the inherently-saferprocess design concept, outlined its basic philosophy and recommended the use of it whenever feasible. In the context of preventing and mitigating dust explosions inherently safer process design could include use of production, treatment, transportation, and storage operations where dust cloud generation is kept at a minimum. One example is the use of mass flow silos and hoppers instead of funnel flow types. Eckhoff [53] emphasized the importance of knowing powder science and technology when striving for inherently safer process design in industries having a dust explosion hazard. Amyotte and Khan [54] proposed a framework for directing the concept of inherently safer process design specifically toward reducing the dust explosion hazard in industry. Recently Amyotte et al. [55] described in greater detail how the inherent safety principles of minimization, substitution, moderation, and simplification can be implemented in practice to prevent and mitigate accidental dust explosions in process plant. Hopefully such initiatives will promote further work in this important area.

4.6. Inerting by Adding Inert Gas. Explosive dust clouds can be made inert by mixing the air with an inert gas such as nitrogen or carbon dioxide to a level at which the dust cloud can no longer propagate a self-sustained flame. Some further insight has been gained during the last two decades. Wilén et al. [56] found that the limiting oxygen concentration (LOC) for inerting of biomass dust clouds increased with increasing initial pressure of the cloud in the range 5 to 18 bar. This is opposite to the decrease of LOC with increasing initial pressure found earlier for clouds of coal dust. As would be expected, Schwenzfeuer et al. [57] found that LOC for ignition of dust clouds by electrostatic discharges, or metal sparks from mechanical impact, was significantly higher than the conservative limit determined in standard tests, using a very strong pyrotechnical ignition source .

Whilst adding nitrogen to the air can prevent dust explosions, it may introduce a suffocation risk. However, it has been shown that addition of a few vol. \% of $\mathrm{CO}_{2}$ to the nitrogen/air mixture reduces the critical oxygen threshold for suffocation considerably . A gas mixture for inerting utilizing this effect was presented by Dansk Fire Eater A/S [58].

4.7. Keeping the Dust Concentration Below LEL. In principle, keeping the concentration of dust in the cloud below the lower explosive limit (LEL) is a means of maintaining dust clouds nonexplosive. However, with a few exceptions the 
method has limited applicability in practice in the process industries. Mittal [59] discussed various mathematical models for calculating minimum explosive concentrations of dust clouds.

\section{Preventing Ignition Sources}

5.1. Smouldering Layers, Deposits, and Nests. Can metal particle sparks from single accidental impacts initiate combustion in dust layers/deposits? Hesby [60] found that the number of sparks from single accidental impacts of steel objects is far too low to be able to cause ignition of the layers of a selection of organic dusts, including tobacco. Gummer and Lunn [61] found that, in general, smouldering nests were poor ignition sources for most dust clouds, whereas flaming nests caused ignition more readily. More work is needed to clarify both the conditions under which smouldering or flaming nests of various materials are generated in industrial plant and the circumstances under which such nests will ignite explosive clouds of various dusts.

Krause and Hensel [62] presented a numerical method by which nonsteady temperature fields in dust deposits can be computed. This enables numerical analysis of a number of practical cases of self heating/self ignition that cannot be analyzed using the classical thermal explosion theory of Frank-Kamenetzki. Krause and Schmidt [63] studied experimentally critical thermal conditions that may lead to initiation of smouldering processes, or to further development of such processes, once initiated.

5.2. Hot Surfaces. In the past, the minimum hot-surface temperature for ignition of a dust cloud has often been regarded as if it were a universal constant for a given cloud. Consequently, results from small-scale laboratory tests were often applied directly in design of large-scale industrial plant. However, minimum hot-surface ignition temperatures of dust clouds vary significantly with scale as well as with the geometry of the hot surface in relation to the dust cloud. There is a need for both a more differentiated basic understanding and a more differentiated testing approach. Development of numerical models for dynamic simulation of hot-surface ignition processes encountered in practice is foreseen.

5.3. Electric/Electrostatic Discharges between Two Metal Electrodes. Electric and electrostatic discharges between two metal electrodes can be generated in a number of ways, for example, in switches, by failures in electric circuits and by discharge of static electricity. The parameters influencing the minimum energy required for igniting a dust cloud by an electric spark include voltage and current characteristics across the spark gap, spark gap geometry, and electrode material as well as all the dust cloud parameters. The latter include particle material and particle size/shape distributions, dust moisture content, dust concentration, and the dynamic state of the dust cloud with respect to the spark gap. Minimum ignition energies (MIEs) of clouds of a given dust material decrease strongly with the fineness of the dust.
Eckhoff [64] discussed the influence of dust fineness on MIE of ferro-alloys dusts. In the past dust fineness was often specified just as a mass percentage finer than an arbitrary size, for example, $74 \mu \mathrm{m}$ or $63 \mu \mathrm{m}$, without any specification of the distribution of particle sizes below these limits. This complicates the analysis of published experimental data, and more systematic research is needed to clarify the exact influence of particle size. In the case of metal alloys the most hazardous components may sometimes accumulate in the fine tail of the particle size distribution (e.g., $\mathrm{Mg}$ in $\mathrm{MgFeSi}$ ), and special investigations are required.

Lorenz and Schiebler [65] presented the results from a comprehensive, detailed experimental and theoretical investigation of the energy transfer processes taking place during an electrostatic spark discharge. The temperature and pressure development in the spark channel during its formation and subsequent expansion were investigated. This also included cooling of the channel by thermal radiation. The dependence of the ability of a given discharged electrical energy to ignite a dust cloud on these basic physical spark characteristics was emphasized.

Randeberg and Eckhoff [66] investigated an alternative method for measuring MIEs of explosive dust clouds, which may be in better accordance with accidental electrostatic spark ignition in industrial plant. They used the transient dust cloud itself to initiate spark breakdown between a pair of electrodes preset at a high voltage somewhat below the breakdown voltage in dust-free air. The MIEs obtained were of the same order as those obtained using the conventional synchronized-spark methods. The lower spark energy limit for apparatuses commonly used for determining MIEs of dust clouds has been 1-3 mJ, but more recently Randeberg et al. [67] presented a new test method that in principle permits MIE determination for dust clouds, using synchronized sparks, down to the order of $0.1 \mathrm{~mJ}$. However, as pointed out by Eckhoff et al. [68], due to the design of the spark generator used, the spark energies quoted by Randeberg et al. were in fact considerably smaller than the real energies in their experiments. Work is currently being conducted at the University of Bergen to eliminate this problem. Whether new MIE measurements using the improved spark discharge circuit will necessitate adjustment of the very low MIEs for some dust clouds reported by Randeberg and Eckhoff [69] and Eckhoff and Randeberg [70] remains to be seen. Recently $\mathrm{Wu}$ et al. [71], using a measurement system with a lower spark energy limit of $1 \mathrm{~mJ}$, reported that clouds in air of a number of very fine titanium and iron powders could be readily ignited by a spark of $1 \mathrm{~mJ}$ energy, which means that their MIEs were in fact significantly lower than this value.

Baudry et al. [72], Nifuku et al. [73], and Marmo and Caravello [74] measured MIEs of clouds in air of various types of dust (aluminium with various contents of oxide, aluminium and magnesium dusts from shedding processes, and nylon fibres, resp.).

5.4. Electrostatic One-Electrode Discharges. With regard to the even more complex one-electrode types of electrostatic discharges (corona, brush, propagating brush, etc.), valuable experimental insight has been gained during the last years. 
For example, the issue of whether brush discharges can ignite dust clouds in air was revisited experimentally by Larsen et al. [75], who were able to ignite clouds of fine sulphur dust in oxygen-enriched air by true brush discharges. However, ignition in air only was never observed. Because of the very low MIE of the sulphur dust used, this indicates that ignition of even the most sensitive dust clouds by brush discharges in air is unlikely.

5.5. Glowing/Burning Particles. Ignition of dust clouds by small burning metal particles called impact sparks or metal particle sparks is a complex process. Such sparks are generated by single, fast impacts between solid materials, of which one is a metal. So far practically useful theories, describing both impact and ignition, do not seem to be within sight. Such theories must comprise several complex subprocesses. The first is the generation and initial heating of the metal particle by the impact. The second is the ignition of the flying hot particle and the subsequent burning process. The third is the heat transfer to the dust cloud, which ultimately determines whether ignition occurs or not.

5.6. Electrical Apparatus. The present situation internationally concerning standards for electrical apparatus for use in areas containing combustible dust is confusing, as discussed by Eckhoff $[76,77]$. The International Electrotechnical Commission (IEC) has decided to base its development on the European Union "Atex" philosophy. However, the European Union Atex 94/9/EC Directive does not distinguish adequately between combustible dusts and combustible gases/vapors. This has given rise to undue alignment of a series of new IEC standards for electrical apparatus for combustible dusts with established standards for gases/vapors. The current European Union Atex 1999/92/EC Directive also lacks the required distinction between gases and dusts, which gives rise to problems with area classification.

5.7. Other Ignition Sources. Proust [78] determined experimentally the minimum laser beam power required for igniting dust clouds by the heat absorbed by a solid target heated by the laser beam. The variable parameters included the laser beam diameter, the duration of the irradiation, the target material (combustible/noncombustible), and the type of dust. Initiation of dust explosions by shock waves has been studied by several workers, including Wolanski [2] and Klemens et al. [79].

\section{Protective/Mitigatory Measures}

6.1. Full Confinement. The applicability of the concept is limited because of high equipment costs. However, the method is used in some special cases, for example, when the powder/dust is highly toxic, and completely reliable confinement is absolutely necessary. Whereas current experimental methods allow accurate prediction of maximum attainable explosion pressures in simple vessels with point source ignition, design of pressure resistant process equipment may not be straightforward. The use of "finite element" computation methods to achieve improved design seems to be inceasing.

6.2. Explosion Isolation. The objective of explosion isolation is to prevent dust explosions from spreading from the primary explosion site to other process units, workrooms, and so forth. Basic understanding of flame propagation and pressure build-up in coupled process equipment ("interconnected vessels") is required for specification of performance criteria of various types of active and passive isolation equipment. van Wingerden et al. [80] reported on dust explosion experiments in a system of two vented vessels connected by a duct. Holbrow et al. [81, 82] summarized the results from extensive similar experiments in the UK and presented coherent quantitative guidance for design of interconnected process equipment based on containment and explosion venting. Vogl and Radandt $[83,84]$ presented results from a comprehensive experimental program in Germany on propagation of dust explosions in interconnected process systems. Various passive and active techniques for interrupting explosions in pipelines have been developed, but there is room for further improvement.

6.3. Partial Inerting. This is a relatively new concept for mitigating dust explosions, which deserves some attention. The idea is that as the oxygen content in the atmosphere is reduced, there is a systematic decrease of both ignition sensitivity and combustion rate of the dust cloud. In many cases the explosion hazard may be reduced markedly by only a moderate reduction of the oxygen content. Glor and Schwenzfeuer [85] confirmed experimentally that even modest reductions of the oxygen content can increase the minimum ignition energies of dust clouds substantially. Devlikanov et al. [86] found that $K_{s t}$ was a linear function of the percentage of oxygen in the gas phase (mixture of nitrogen and oxygen). Conde Lázaro and García Torrent [87] carried out a series of partial inerting experiments at 12 bar initial pressure, in a demonstration pulverized coal power plant. Eckhoff [88] called for more extensive use of partial inerting in industrial dust explosion protection at large.

6.4. Explosion Venting. This is probably the most widely used method for mitigating dust explosions. In spite of extensive research and development, dust explosion venting remains a complex and in part controversial subject. The key issue is vent area sizing.

Tamanini and Valiulis [89] presented an improved version of the VDI (Germany) and NFPA (USA) guidelines for sizing of dust explosion vents. The improvement was achieved by systematizing the data in the context of a simplified physical model of the vented explosion. A similar contribution was made by Ural [90]. The new CEN [91] standard for design of dust explosion venting systems in principle opens up for a differentiated approach to vent sizing, which accounts for the variations in dust cloud structures encountered in practice in industry. In most practical cases this will result in more liberal vent area requirements than those of some previous rigorous standards. 
Other aspects of explosion venting studied more recently include the influence of the inertia and specific design of the vent cover on the gas dynamics of the venting process. A further dimension of complexity is added to the venting problem if the initial pressure (and/or temperature) deviates from atmospheric. Results from venting of dust explosions in air at elevated initial pressure were reported by Siwek et al. [92].

In dust explosion venting, maintaining the integrity of the enclosure is not the only concern. Venting implies that both blast waves and flames are emitted into the surroundings, and this may present a hazard, depending on the size of the emitted flame and the magnitude of the blast wave. Several workers, including Forcier and Zalosh [93], Holbrow et al. [94] and Harmanny [95], investigated various aspects of this problem. Various methods have been developed for eliminating hazardous effects of flames from vent openings. Li et al. [96] and Emde and Penno [97] discussed further aspects of the Q-pipe for dust and flamefree venting. The influence of vent ducts on the maximum explosion pressure in the vented vessel has been studied experimentally by several workers including Ural [98] and Lunn [99]. Tamanini and Valiulis [100] presented a new theoretical approach for predicting the resultant reaction impulse acting on a process structure during a vented explosion.

Venting of industrial buildings requires special considerations. An overview was given by Crowhurst [101]. Höppner [102] discussed the design of dust explosion venting arrangements for rooms/buildings of volumes $>5000 \mathrm{~m}^{3}$, with walls that can only withstand overpressures less than 0.2 bar. In case of a dust explosion, only part of such large volumes will be filled with explosive dust cloud.

Tamanini [103] summarized his valuable effort of correlating existing experimental dust explosion venting data by applying the classical method of dimensional analysis. It is regrettable that this important work was not included in the recent European Union guideline for design dust explosion venting arrangements, CEN [91], but it has been included in recent US standards (NFPA). Silvestrini et al. [104] developed correlations for flame speed and explosion overpressure for dust explosions inside industrial enclosures with the aim to provide a simple tool for sizing dust explosion vents.

However, in view of the different turbulence levels, degrees of dust dispersion, and distributions of dust concentrations encountered in industry, the need for a more complete differentiated approach to assessment of vent area requirements has gained general acceptance. As indicated by Skjold [34], the numerical code DESC may become a useful tool to meet this need.

6.5. Automatic Explosion Suppression. This active method for dust explosion mitigation is comparatively complex and expensive. It is therefore used when simpler and less expensive methods are inadequate. The method has been in use for many decades, and significant progress has been made during the last decade. For example, Moore [105] and Chatrathi and Going [106] evaluated the suitability of various suppressants, and Tyldesley [107] reported that superheated water can in some circumstances be an effective candidate. Moore and Siwek [108] summarized their extensive multiyear experimental work on suppression of dust explosions, whereas Chatrathi and Going [109] gave an overview of current technology and philosophy for implementing automatic explosion suppression systems in practice. The influence of elevated initial temperature of the explosive dust cloud on the efficacy of an automatic explosion suppression system was studied by Brehm [110].

The European standardization organization CEN [111] has produced a draft standard for design of explosion suppression systems, which seems to open up for greater flexibility than the traditional, mostly very conservative approach. Hence, if the turbulence level and/or degree of homogeneity of the cloud of a given dust in the actual process situation are lower than those produced by the rather conservative traditional standard VDI-method of dust cloud generation, this can be accounted for in the design of the suppression system.

Comprehensive numerical models of the complex explosion suppression process, based on computational fluid dynamics (CFD), are likely to be the future tool for design of optimal explosion suppression systems. Again the code DESC should be mentioned as a promising candidate. Morgan [112] assessed the suitability of commercially available CFD software for modeling the types of flows encountered in explosion suppression processes. Using results from his model simulations, he was able to design a novel suppressant injection nozzle, which was shown to be more effective than standard nozzles currently used.

6.6. Design of Process Equipment for Specific Internal Explosion Loads. This problem is also addressed in 6.1 above and is a central concern also when designing explosion venting systems (6.4) and systems for automatic explosion suppression (6.5). Harmanny [113] presented a new equation for predicting the duration of vented dust explosions in enclosures of volumes from 10 to $60 \mathrm{~m}^{3}$. This is a useful tool for evaluating whether static pressure considerations or impulse considerations apply when predicting the response of the enclosure structure to the explosion load. Harmanny $[114,115]$ revisited the problem of assessing the structural response of a given process equipment and buildings to explosion loads. With regard to dust explosions in the process industries, he concluded that most often they are sufficiently slow for the load to be regarded as quasistatic. However, there are certain cases where dynamic effects play a significant role. Comprehensive finite-element-based computer codes for determining detailed stress/strain analyses of complex structures exposed to defined static and dynamic loads have been available for some time. It is foreseen that the use of such tools in assessing the explosion strength of complex process equipment will increase in the years to come. The concept of pressure-shock-resistant design should be developed further to facilitate cost effective equipment design. Li et al. [116] compared elastic and plastic structural responses of a simple mechanical structure determined experimentally with predictions from using a computational finite-element approach. 
6.7. Preventing Secondary Explosions Outside Process Equipment. This remains a most important issue in all efforts to fight the dust explosion hazard. Adequate housekeeping is an essential means of achieving this aim. However, there are still questions to be answered concerning the level of cleanliness required. More research is needed for assessment of the maximum acceptable mass of deposited dust per unit area of surface for preventing secondary dust flame propagation under various conditions. Cybulski et al. [117] showed that comparatively weak secondary dust explosions in short narrow tunnels in grain elevators can be extinguished by properly designed, actively triggered water barriers. They also showed that, under the conditions prevailing, the possibility of flame penetration into blind gallery branches was small. This kind of work may also be of relevance to the analysis of flame propagation in large industrial systems, for example, in grain storage and handling plants.

\section{Other Factors Influencing the Dust Explosion Risk}

7.1. Explosion Risk Management. Barth [118] emphasized the importance of companies establishing systems for explosion risk management control to ensure effective, longlasting explosion protection of process plant. Hesener et al. [119], with reference to the pharmaceutical industry, underlined the need for having adequate systems for explosion risk management and control even in small and medium size plants. van der Voort et al. [120] presented a quantitative risk assessment tool for the external safety of industrial plants with a dust explosion hazard.

7.2. Cost/Benefit in Dust Explosion Prevention and Mitigation. Alfert [121] addressed the bottom-line costs of various dust explosion protection systems on the market. Janssens [122] pointed out that the investments required to achieve proper prevention and control of the explosion hazard in a given plant are not necessarily excessive. By combining thorough knowledge of the processes to be protected, with knowledge of relevant ignition and flame propagation phenomena, and principles and technologies available for explosion control, good solutions can be obtained at an acceptable cost.

7.3. Education and Training. High safety levels in the process industries cannot be established once and for all by a single all-out effort. Deterioration results if the high level once attained is not actively secured by continuous maintenance and renewal. This applies both to technology and human factors. Education and training, from short practical training courses to in-depth long-term education, play a key role in the continuous maintenance and renewal process. Universities and colleges have responded to this challenge by establishing study courses on a wide range of process safety aspects. Relevant topics include reliability and risk analysis, the physics, chemistry, and technology of processes and hazards, and means of accident prevention and mitigation. Much emphasis has been put on methods of reliability and risk analysis, which are indeed very important. However, it is sometimes felt by the process industry itself that education in the "hard" aspects, that is, the physics, chemistry, and technology of processes and process hazards, has been somewhat left behind. This situation presents a special challenge to universities and colleges.

\section{Perspectives for the Future}

(a) The approaches taken in dust explosion prevention and mitigation in the process industries will become steadily less dogmatic and more tailored and differentiated in the years to come. Industry will strive for steadily more cost effective safety measures.

(b) Therefore, substantial progress is foreseen in mathematical CFD-based modeling of dust cloud generation and flame propagation processes in dust clouds. It is anticipated that such models will gradually replace conventional empirical equations and graphs as design tools for tailored systems for explosion isolation, explosion venting, and automatic explosion suppression and for evaluating consequences of secondary dust explosions. However, extensive experimental validation of the numerical models is absolutely necessary.

(c) Evaluation of potential ignition sources will also become more detailed and differentiated, in accordance with reality. Further development of mathematical models capable of predicting ignition of dust clouds and layers by self-heating/smouldering, hot surfaces, various electrical and electrostatic sparks/discharges, metal sparks, and so forth, is foreseen.

(d) Combined protective solutions, for example, partial inerting in combination with venting, or venting combined with automatic suppression, are likely to be used to an increasing extent.

(e) The need for inherently, safer design of processes for production, treatment and handling of combustible powders/dusts is expected to be become more and more accepted. To achieve this, knowledge and systematic use of powder/particle science and technology is a basic requirement.

(f) High-quality training/education, ranging from short courses of a few days to extensive university studies, will continue to be essential for minimizing the hazards in the process industries, including minimizing the risk of dust explosions.

\section{References}

[1] J. H. S. Lee, F. Zhang, and R. Knystautas, "Propagation mechanisms of combustion waves in dust-air mixtures," Powder Technology, vol. 71, no. 2, pp. 153-162, 1992.

[2] P. Wolanski, Deflagration, Detonation and Combustion of Dust Mixtures, American Institute of Aeronautics and Astronautics, New York, NY, USA, 1990.

[3] R. K. Eckhoff, "Generation, ignition, combustion and explosion of sprays and mists of flammable liquids in air. 
A Literature Survey," Tech. Rep. CMI-91-A25014, Christian Michelsen Institute, Fantoft, Norway, 1991.

[4] R. K. Eckhoff, Dust Explosions in the Process Industries, Gulf Professional Publishing/Elsevier, Boston, Mass, USA, 3rd edition, 2003.

[5] S. M. Frolov, K. A. Avdeev, and F. S. Frolov, "Effect of transient heat transfer on ignition of solid particles," Journal of Loss Prevention in the Process Industries, vol. 20, no. 4-6, pp. 310-316, 2007.

[6] A. V. Fedorov and A. V. Shulgin, "About stability of the ignition process of small solid particle," Journal of Loss Prevention in the Process Industries, vol. 20, no. 4-6, pp. 317321, 2007.

[7] A. E. Dahoe, K. Hanjalic, and B. Scarlett, "Determination of the laminar burning velocity and the Markstein length of powder-air flames," Powder Technology, vol. 122, no. 2-3, pp. 222-238, 2002.

[8] I. O. Moen, J. H. S. Lee, and B. H. Hjertager, "Pressure development due to turbulent flame propagation in largescale methane-air explosions," Combustion and Flame, vol. 47, pp. 31-52, 1982.

[9] B. H. Hjertager, K. Fuhre, and M. Bjoerkhaug, "Gas explosion experiments in 1:33 and 1:5 scale offshore separator and compressor modules using stoichiometric homogeneous fuel/air mixtures," Journal of Loss Prevention in the Process Industries, vol. 1, no. 4, pp. 197-220, 1988.

[10] J. R. Bakke and K. van Wingerden, Guidance for Designing Offshore Modules Evolving from Gas Explosion Research, Society of Petroleum Engineers, Richardson, Tex, USA, 1992.

[11] F. Rzal-Rebière and B. Veyssière, "Propagation mechanisms of starch particles-air flames," in Proceedings of the 6th International Colloquium on Dust Explosions, D. Xufan and P. Wolanski, Eds., pp. 186-200, Shenyang, China, AugustSeptember 1994.

[12] P. Mitgau, Einfluss der Turbulenzlänge und der Schwankungsgeschwindichkeit auf die Verbrennungs-geschwindigkeit von aerosolen, vol. 14, Max-Planck-Institut Für Strömungsforschung, Göttingen, Germany, 1996.

[13] P. Mitgau, H. Gg. Wagner, and R. Klemens, "Einfluss der Turbulenzlänge und der Schwankungsgeschwindichkeit auf die Flammengeschwindigkeit von Stäuben," in Feuerungstechnik, Kaleidoskop aus aktueller Forschung und Entwicklung. Geburtstag, Festschrift an Prof. Wolfgang Leuckel zu seinem 65, pp. 17-45, Engler-Bunte-Institut, Bereich Feuerungstechnik, Universität Karlsruhe (TH), Geburtstag, Germany, 1997.

[14] K. L. Cashdollar and I. A. Zlochower, "Explosion temperatures and pressures of metals and other elemental dust clouds," Journal of Loss Prevention in the Process Industries, vol. 20, no. 4-6, pp. 337-348, 2007.

[15] L. Kjäldman, "Numerical flow simulation of dust deflagrations," Powder Technology, vol. 73, no. 1, p. 100, 1992.

[16] M. Rose, P. Roth, S. M. Frolov, and M. G. Neuhaus, "Modelling of turbulent gas/particle combustion by a Lagrangian PDF method," Combustion Science and Technology, vol. 149, no. 1, pp. 95-113, 1999.

[17] N. N. Smirnov, V. F. Nikitin, and J. C. Legros, "Ignition and combustion of turbulized dust-air mixtures," Combustion and Flame, vol. 123, no. 1-2, pp. 46-67, 2000.

[18] U. Bielert and M. Sichel, "Numerische simulation von staubexplosionen in pneumatischen saug-flug-förderanlagen," VDI-Berichte, no. 1601, pp. 449-472, 2001.

[19] K. Wörsdörfer, M. Sippel, J. Fuisting, and A. Kneer, "Möglichkeiten des Einsatzes numerischer Methoden im
Explosionsschutz," VDI-Berichte, no. 1601, pp. 437-447, 2001.

[20] V. P. Korobeinikov, I. V. Semenov, I. S. Menshov, R. Klemens, P. Wolanski, and P. Kosinski, "Modelling of flow and combustion behind shock waves propagating along dust layers in long ducts," Journal de Physique IV, vol. 12, no. 7, pp. Pr7/113-Pr7/119, 2002.

[21] S. Zhong, A. Teodorczyk, X. Deng, and J. Dang, "Modeling and simulation of coal dust explosions," Journal de Physique IV, vol. 12, no. 7, pp. Pr7/141-Pr7/147, 2002.

[22] P. Kosinski, R. Klemens, and P. Wolanski, "Potential of mathematical modelling in large-scale dust explosions," Journal de Physique IV, vol. 12, no. 7, pp. Pr7/125-Pr7/132, 2002.

[23] A. Di Benedetto and P. Russo, "Thermo-kinetic modelling of dust explosions," Journal of Loss Prevention in the Process Industries, vol. 20, no. 4-6, pp. 303-309, 2007.

[24] K. van Wingerden, B. J. Arntzen, and P. Kosiński, "Modelling of dust explosions," VDI-Berichte, no. 1601, pp. 411-421, 2001.

[25] B. J. Arntzen, H. C. Salvesen, H. F. Nordhaug, I. E. Storvik, and O. R. Hansen, "CFD-modelling of oil mist and dust explosion experiments," in Proceedings of the 4th International Seminar on Fire and Explosion Hazards, pp. 601-608, Londonderry, UK, September 2003.

[26] O. R. Hansen, T. Skjold, and B. J. Arntzen, "DESCa CFD tool for dust explosions," in Proceedings of the 3rd International ESMG Symposium on Process Safety and Industrial Explosion Protection, Nürnberg, Germany, March 2004.

[27] R. Siwek, K. Wingerden, O. R. van Hansen, et al., "Dust explosion venting and suppression of conventional spray dryers," in Proceedings of the 11th International Symposium Loss Prevention and Safety Promotion in the Process Industries, Praha, Czech Republic, May-June 2004.

[28] T. Skjold, B. J. Arntzen, O. R. van Hansen, I. Storvik, and R. K. Eckhoff, "Simulation of dust explosions in complex geometries with experimental input from standardized tests," in Proceedings of the 5th International Symposium on Hazards, Prevention and Mitigation of Industrial Explosions (ISHPMIE '04), Krakow, Poland, October 2004.

[29] T. Skjold, B. J. Arntzen, O. R. van Hansen, O. J. Taraldset, I. Storvik, and R. K. Eckhoff, "Simulating dust explosions with the first version of DESC," in Proceedings of the Symposium on Hazards XVIII: Process Safety-Shearing Best Practice, IChemE NW Branch Symposium, UMIST, Manchester, UK, November 2004.

[30] T. Skjold, B. J. Arntzen, O. R. van Hansen, O. J. Taraldset, I. E. Storvik, and R. K. Eckhoff, "Simulating dust explosions with the first version of DESC," Process Safety and Environmental Protection, vol. 83, no. 2, pp. 151-160, 2005.

[31] T. Skjold, B. J. Arntzen, O. R. van Hansen, I. E. Storvik, and R. K. Eckhoff, "Simulation of dust explosions in complex geometries with experimental input from standardized tests," Journal of Loss Prevention in the Process Industries, vol. 19, no. 2-3, pp. 210-217, 2006.

[32] T. Skjold, "Review of the DESC project," in Proceedings of the 6th International Symposium on Hazards, Prevention, and Mitigation of Industrial Explosions (ISHPMIE '06), pp. 1-21, Halifax, Canada, August-September 2006, (Key-note paper).

[33] T. Skjold, R. K. Eckhoff, B. J. Arntzen, et al., "Simplified modelling of explosion propagation by dust lifting in coal mines," in Proceedings of the 5th Intenational Seminar on 
Fire and Explosion Hazards, The University of Edinburgh, Scotland, UK, April, 2007.

[34] T. Skjold, "Review of the DESC project," Journal of Loss Prevention in the Process Industries, vol. 20, no. 4-6, pp. 291302, 2007.

[35] R. Weber, "Preisgekrönte Abhandlung über die Ursachen von Explosionen und Bränden in Mühlen, sowie über die Sicherheitsmassregein zur Verhütung derselben," Verhandlungen des Vereins zur Beförderung des Gewerbe-fleißes, pp. 83-103, 1878.

[36] F. Hauert, A. Vogl, and S. Radandt, "Measurement of turbulence and dust concentration in silos and vessels," in Proceedings of the 6th International Colloquium on Dust Explosions, D. Xufan and P. Wolanski, Eds., pp. 71-80, Shenyang, China, August-September 1994.

[37] P. Kosinski, R. Klemens, P. Wolanski, V. P. Korobeinikov, V. V. Markov, and I. S. Men'shov, "Dust-air mixtures spreading in branched ducts," in Proceedings of the 18th International Colloquium Dynamics Exploration \& Reaction System, Seattle, Wash, USA, 2001.

[38] P. Kosinski and A. C. Hoffmann, "Modelling of dust lifting using the Lagrangian approach," International Journal of Multiphase Flow, vol. 31, no. 10-11, pp. 1097-1115, 2005.

[39] P. Kosinski, A. C. Hoffmann, and R. Klemens, "Dust lifting behind shock waves: comparison of two modelling techniques," Chemical Engineering Science, vol. 60, no. 19, pp. 5219-5230, 2005.

[40] C. G. Ilea, P. Kosinski, and A. C. Hoffmann, "Threedimensional simulation of a dust lifting process with varying parameters," International Journal of Multiphase Flow, vol. 34, no. 9, pp. 869-878, 2008.

[41] K. Lebecki, J. Sliz, Z. Dyduch, and P. Wolanski, Critical Dust Layer Thickness for Combustion of Grain Dust, American Institute of Aeronautics and Astronautics, New York, NY, USA, 1990.

[42] C. W. Kauffman, M. Sichel, and P. Wolanski, "Research on dust explosions at the University of Michigan," Powder Technology, vol. 71, no. 2, pp. 119-134, 1992.

[43] P. J. Austin, F. Girodroux, Y. C. Li, C. G. Alexander, C. W. Kauffman, and M. Sichel, "Recent progress in the study of dust combustion phenomena at the University of Michigan," in Proceedings of the 5th International Colloquium on Dust Explosions, pp. 211-214, Pultusk, Poland, April 1993.

[44] V. M. Boiko and S. V. Poplavski, "On the effect of particle concentration on acceleration of a dusty cloud behind a shock wave," in Proceedings of the 7th International Colloquium on Dust Explosions, GexCon AS, Bergen, Norway, June 1996.

[45] R. Klemens, P. Kosinski, and P. Oleszczak, "Mathematical modelling of dust layer dispersion by rarefaction waves," Archivum Combustionis, vol. 22, no. 1-2, pp. 3-12, 2002.

[46] A. V. Fedorov and Yu. A. Gosteev, "Quantitative description of lifting and ignition of organic fuel dusts in shock waves," Journal de Physique IV, vol. 12, no. 7, pp. Pr7/89-Pr7/95, 2002.

[47] A. V. Fedorov and N. N. Fedorova, "Numerical simulations of dust lifting under the action of shock wave propagating along the near-wall layer," Journal de Physique IV, vol. 12, no. 7, pp. Pr7/97-Pr7/104, 2002.

[48] F. Tamanini and E. A. Ural, "FMRC studies of parameters affecting the propagation of dust explosions," Powder Technology, vol. 71, no. 2, pp. 135-151, 1992.
[49] J. A. H. de Jong, A. C. Hoffmann, and H. J. Finkers, "Properly determine powder flowability to maximize plant output," Chemical Engineering Progress, vol. 95, no. 4, pp. 25-34, 1999.

[50] N.O. Breum, "The rotating drum dustiness tester: variability in dustiness in relation to sample mass, testing time, and surface adhesion," Annals of Occupational Hygiene, vol. 43, no. 8, pp. 557-566, 1999.

[51] D. Dahmann and K. Möcklinghoff, "Das Staubungsverhalten quarzfeinstaubhaltige Produkte," Gefahrstoffe- Reinhaltung der Luft, vol. 60, pp. 213-215, 2000.

[52] T. Kletz, "Inherently safer design: avoidance better than control," in Proceedings of the 3rd World Seminar on the Explosion Phenomenon and on the Application of Explosion Protection Techniques in Practice, Flanders Expo, Gent, Belgium, February 1999.

[53] R. K. Eckhoff, "Understanding dust explosions. The role of powder science and technology," Journal of Loss Prevention in the Process Industries, vol. 22, no. 1, pp. 105-116, 2009.

[54] P. R. Amyotte and F. I. Khan, "An inherent safety framework for dust explosion prevention and mitigation," Journal de Physique IV, vol. 12, no. 7, pp. Pr7/189-Pr7/196, 2002.

[55] P. R. Amyotte, M. J. Pegg, and F. I. Khan, "Application of inherent safety principles to dust explosion prevention and mitigation," Process Safety and Environmental Protection, vol. 87, no. 1, pp. 35-39, 2009.

[56] C. Wilén, A. Rautalin, J. García-Torrent, and E. CondeLázaro, "Inerting biomass dust explosions under hyperbaric working conditions," Fuel, vol. 77, no. 9-10, pp. 1089-1092, 1998.

[57] K. Schwenzfeuer, M. Glor, and A. Gitzi, "Relation between ignition energy and limiting oxygen concentrations for powders," in Proceedings of the 10th International Symposium Loss Prevention and Safety Promotion in the Process Industries, H. J. Pasman, O. Fredholm, and A. Jacobsson, Eds., pp. 909916, Elsevier, Stocholm, Sweden, June 2001.

[58] Dansk Fire Eater A/S, "INERGEN. Anlœgsbeskrivelse \& Design," Report, Dansk Fire Eater A/S, Holte, Denmark, 1992.

[59] M. Mittal, "Mathematical models for minimum explosible concentration of dusts," in Proceedings of the 5th International Colloquium on Dust Explosions, pp. 247-256, Pultusk, Poland, April 1993.

[60] I. Hesby, Ignition of dust layers by metal particle sparks, M.Sc. thesis, Department of Physics, University of Bergen, Bergen, Norway, 2000.

[61] J. Gummer and G. Lunn, "Ignitions of explosive dust clouds by smouldering and flaming agglomerates," Journal of Loss Prevention in the Process Industries, vol. 16, no. 1, pp. 27-32, 2003.

[62] U. Krause and W. Hensel, "Zündgefahren lagernder Staubschüttungen-Neue Hilfsmittel für ihre Bewertung," VDIBerichte, no. 1272, pp. 183-201, 1996.

[63] U. Krause and M. Schmidt, "Untersuchungen zur Zündung und Ausbreitung von Schwelbränden in Stäuben und Schüttgütern,” VDI-Berichte, no. 1601, pp. 397-410, 2001.

[64] R. K. Eckhoff, "Dust explosion hazards in the ferro-alloys industry," in Proceedings of the 52nd Electric Furnace Conference, pp. 283-302, Iron and Steel Society, Nashville, Tenn, USA, November 1995.

[65] D. Lorenz and H. Schiebler, "Optische Temperaturmessung an Entladungsfunken im Hinblick auf deren Zündwirksamkeit bei Staubexplosionen," VDI-Berichte, no. 1601, pp. 653-667, 2001. 
[66] E. Randeberg and R. K. Eckhoff, "Initiation of dust explosions by electric spark discharges triggered by the explosive dust cloud itself," in Proceedings of the 5th International Symposium on Hazards, Prevention and Mitigation of Industrial Explosions (ISHPMIE '04), Krakow, Poland, October 2004.

[67] E. Randeberg, W. Olsen, and R. K. Eckhoff, "A new method for generation of synchronised capacitive sparks of low energy," Journal of Electrostatics, vol. 64, no. 3-4, pp. 263-272, 2006.

[68] R. K. Eckhoff, W. Olsen, and O. Kleppa, "Influence of spark discharge duration on the minimum ignition energy of premixed propane/air," in Proceedings of the 7th International Symposium on Hazards, Prevention, and Mitigation of Industrial Explosions (ISHPMIE '08), vol. 1, pp. 44-53, St. Petersburg, Russia, July 2008.

[69] E. Randeberg and R. K. Eckhoff, "Measurement of minimum ignition energies of dust clouds in the $<1 \mathrm{~mJ}$ region," Journal of Hazardous Materials, vol. 140, no. 1-2, pp. 237-244, 2007.

[70] R. K. Eckhoff and E. Randeberg, "Electrostatic spark ignition of sensitive dust clouds of MIE $<1 \mathrm{~mJ}$," Journal of Loss Prevention in the Process Industries, vol. 20, no. 4-6, pp. 396401, 2007.

[71] H.-C. Wu, R.-C. Chang, and H.-C. Hsiao, "Research of minimum ignition energy for nano titanium powder and nano Iron powder," Journal of Loss Prevention in the Process Industries, vol. 22, no. 1, pp. 21-24, 2009.

[72] G. Baudry, S. Bernard, and P. Gillard, "Influence of the oxide content on the ignition energies of aluminium powders," Journal of Loss Prevention in the Process Industries, vol. 20, no. 4-6, pp. 330-336, 2007.

[73] M. Nifuku, S. Koyanaka, H. Ohya, et al., "Ignitability characteristics of aluminium and magnesium dusts that are generated during the shredding of post-consumer wastes," Journal of Loss Prevention in the Process Industries, vol. 20, no. 4-6, pp. 322-329, 2007.

[74] L. Marmo and D. Cavallero, "Minimum ignition energy of nylon fibres," Journal of Loss Prevention in the Process Industries, vol. 21, no. 5, pp. 512-517, 2008.

[75] Ø. Larsen, J. H. Hagen, K. van Wingerden, and R. K. Eckhoff, "Ignition of dust clouds by brush discharges in oxygen enriched atmospheres," Gefahrstoffe-Reinhaltung der Luft, vol. 61, no. 3, pp. 85-90, 2001.

[76] R. K. Eckhoff, "A critical view on the treatment of combustible powders/dusts in the European 'Atex 100a' and 'Atex 118a' Directives," in Proceedings of the 3rd International ESMG Symposium on Process Safety and Industrial Explosion Protection, Nürnberg, Germany, March 2004.

[77] R. K. Eckhoff, "Inadequate treatment of dust explosions and fires in 'ATEX'. A critical view on resulting standards for electrical apparatus," Bulk Solids \& Powder Science \& Technology. In press.

[78] Ch. Proust, "Laser ignition of dust clouds," Journal de Physique IV, vol. 12, no. 7, pp. Pr7/79-Pr7/88, 2002.

[79] R. Klemens, P. Wolanski, and J. Klammer, "On unsteady flows of combustible dusty gases caused by a shock wave propagation," in Proceedings of the 8th International Colloquium on Dust Explosions, pp. 355-363, Safety Consulting Engineers, Schaumburg, Ill, USA, September 1998.

[80] K. van Wingerden, G. H. Pedersen, G. H. Teigland, and R. K. Eckhoff, "Violence of dust explosions in integrated systems," in Proceedings of the 28th AIChE Annual Loss Prevention Symposium, American Institute of Chemical Engineers, Atlanta, Ga, USA, April 1995, Session no. 13 on Dust Explosions.
[81] P. Holbrow, S. Andrews, and G. A. Lunn, "Dust explosions in interconnected vented vessels," Journal of Loss Prevention in the Process Industries, vol. 9, no. 1, pp. 91-103, 1996.

[82] P. Holbrow, G. A. Lunn, and A. Tyldesley, "Dust explosion protection in linked vessels: guidance for containment and venting," Journal of Loss Prevention in the Process Industries, vol. 12, no. 3, pp. 227-234, 1999.

[83] A. Vogl and S. Radandt, "Explosionsübertragung durch dünne Rohrleitungen," VDI-Berichte, no. 1601, pp. 575-594, 2001.

[84] A. Vogl and S. Radandt, "Explosionsübertragung durch dünne Rohrleitungen,” Tech. Rep. 05-9903, Forsch.gesellsch. angew. Systemsicherheit und Arbeitsmedizin, Mannheim, Germany, 2002.

[85] M. Glor and K. Schwenzfeuer, "Einfluss der Sauerstoffkonzentration auf die Mindestzündenergie von Staüben," in Dechema Jahrestagung, Wiesbaden, Germany, April 1999.

[86] O. Devlikanov, D. K. Kuzmenko, and N. L. Poletaev, "Nitrogen dilution for explosion of nutrient yeast dust/air mixture," Fire Safety Journal, vol. 25, no. 4, p. 373, 1995.

[87] E. Conde Lázaro and J. García Torrent, "Experimental research on explosibility at high initial pressures of combustible dusts," Journal of Loss Prevention in the Process Industries, vol. 13, no. 3-5, pp. 221-228, 2000.

[88] R. K. Eckhoff, "Partial inerting-an additional degree of freedom in dust explosion protection," Journal of Loss Prevention in the Process Industries, vol. 17, no. 3, pp. 187-193, 2004.

[89] F. Tamanini and J. V. Valiulis, "Improved guidelines for the sizing of vents in dust explosions," Journal of Loss Prevention in the Process Industries, vol. 9, no. 1, pp. 105-118, 1996.

[90] E. A. Ural, "A simplified development of a unified dust explosion vent sizing formula," in Proceedings of the 35th Annual Loss Prevention Symposium, American Institute of Chemical Engineers, Houston, Tex, USA, April 2001.

[91] CEN, "Dust explosion venting protective systems," European Union draft standard prEN 14491 (CEN/TC 305/WG 3/SG 5N, 27 February 2002) prepared by CEN/TC 305 'Potentially explosive atmospheres. Explosion prevention and protection', 2002.

[92] R. Siwek, M. Glor, and T. Torreggiani, "Dust explosion venting at elevated initial pressure," in Proceedings of the 7th International Symposium Loss Prevention and Safety Promotion in the Process Industries, pp. 57-1-57-15, SRPPartners, Roma, Italy, May 1992.

[93] T. Forcier and R. Zalosh, "External pressures generated by vented gas and dust explosions," Journal of Loss Prevention in the Process Industries, vol. 13, no. 3-5, pp. 411-417, 2000.

[94] P. Holbrow, S. J. Hawksworth, and A. Tyldesley, "Thermal radiation from vented dust explosions," Journal of Loss Prevention in the Process Industries, vol. 13, no. 6, pp. 467476, 2000.

[95] A. Harmanny, "Pressure effects from vented dust explosions," VDI-Berichte, no. 1601, pp. 539-550, 2001.

[96] G. Li, X. Deng, W. Liu, et al., "Development of a quenching venting door (QVD)," in Proceedings of the 6th International Colloquium on Dust Explosions, D. Xufan and P. Wolanski, Eds., pp. 530-534, Shenyang, China, August-September 1994.

[97] A. Emde and B. Penno, "Einbindung der Sauerstoffverdrängung und des Kontraktionseffektes mit angepasstem Wiederstandsbeiwert Zeta bei der Entwicklung neuartiger Quenchvorrichtungen zur Explosionsdruckentlastung innerhalb von Räumen," VDI-Berichte, no. 1272, pp. 645-651, 1996. 
[98] E. A. Ural, "A simplified method for predicting the effect of ducts connected to explosion vents," Journal of Loss Prevention in the Process Industries, vol. 6, no. 1, pp. 3-10, 1993.

[99] G. A. Lunn, "Institution of chemical engineers vent duct method applied to the VDI vent sizing technique," VDIBerichte, no. 1601, pp. 513-526, 2001.

[100] F. Tamanini and J. V. Valiulis, "A correlation for the impulse produced by vented explosions," Journal of Loss Prevention in the Process Industries, vol. 13, no. 3-5, pp. 277-289, 2000.

[101] D. Crowhurst, "Explosion protection of industrial buildings," The European Summer School on Dust Explosion Hazards: Their Assessment and Control, organized by IBC Technical Services, in association with BMHB and IELG, Cambridge, UK, 1993.

[102] K. Höppner, "Explosionsdruckentlastung von Gebäuden," VDI-Berichte, no. 1272, pp. 327-346, 1996.

[103] F. Tamanini, "Dust explosion vent sizing. Current methods and future developments," Journal de Physique IV, vol. 12, no. 7, pp. Pr7/31-Pr7/44, 2002.

[104] M. Silvestrini, B. Genova, and F. J. Leon Trujillo, "Correlations for flame speed and explosion overpressure of dust clouds inside industrial enclosures," Journal of Loss Prevention in the Process Industries, vol. 21, no. 4, pp. 374392, 2008.

[105] P. E. Moore, "Suppressants for the control of industrial explosions," Journal of Loss Prevention in the Process Industries, vol. 9, no. 1, pp. 119-123, 1996.

[106] K. Chatrathi and J. Going, "Effectiveness of dust explosion suppressants," in Proceedings of the 9th International Symposium on Loss Prevention and Safety Promotion Process Industry, pp. 1008-1017, Barcelona, Spain, May 1998.

[107] A. Tyldesley, "Private letter to R. K. Eckhoff," November 1993.

[108] P. E. Moore and R. Siwek, "Explosion suppression overview," in Proceedings of the 9th International Symposium Loss Prevention and Safety Promotion in the Process Industries, pp. 745-758, Barcelona, Spain, May 1998.

[109] K. Chatrathi and J. Going, "Dust deflagration extinction," Process Safety Progress, vol. 19, no. 3, pp. 146-153, 2000.

[110] K. Brehm, "Explosionsunterdrückung bei erhöhter temperatur," VDI-Berichte, no. 1272, pp. 261-272, 1996.

[111] CEN, "Explosion suppression systems," European Union draft standard prEN 14373 (CEN/TC 305 WI 00305032, August 2001) prepared by CEN/TC 305 'Potentially explosive atmospheres. Explosion prevention and protection', 2001.

[112] A. J. Morgan, The arresting of explosions to minimize environmental damage, Ph.D. thesis, Department of Mechanical Engineering, Brunel University, Uxbridge, UK, 2000.

[113] A. Harmanny, "Duration of vented dust explosions," EuropEx Newsletter, vol. 23, pp. 5-9, 1993.

[114] A. Harmanny, "Structural aspects related to explosion protection techniques," in Proceedings of the 2nd World Seminar on the Explosion Phenomenon and on the Application of Explosion Protection Techniques in Practice, EuropEx, Gent, Belgium, March 1996.

[115] A. Harmanny, "Structural aspects related to explosion resistance of process buildings, structures and silos," in Proceedings of the 3rd World Seminar on the Explosion Phenomenon and on the Application of Explosion Protection Techniques in Practice, Flanders Expo, Gent, Belgium, February 1999.

[116] G. Li, B.-Z. Chen, X.-F. Deng, and R. K. Eckhoff, "Explosion resistance of a square plate with a square hole," Journal de Physique IV, vol. 12, no. 7, pp. Pr7/121-Pr7/124, 2002.
[117] K. Cybulski, Z. Dyduch, K. Lebecki, and J. Sliz, "Suppression of grain dust explosions with triggered barriers," in Proceedings of the 5th International Colloquium on Dust Explosions, pp. 437-447, Pultusk, Poland, April 1993.

[118] U. Barth, "Explosionsgefahren managen—systematisch oder mit system?” VDI-Berichte, no. 1601, pp. 207-223, 2001.

[119] U. Hesener, U. Barth, and B. Dyrba, "Erstellung von Explosionsschutzdokumenten anhand von Anlagenbeispielen der pharmazeutischen Industrie," VDI-Berichte, no. 1601, pp. 225-237, 2001.

[120] M. M. van der Voort, A. J. J. Klein, M. de Maaijer, A. C. van den Berg, J. R. van Deursen, and N. H. A. Versloot, "A quantitative risk assessment tool for the external safety of industrial plants with a dust explosion hazard," Journal of Loss Prevention in the Process Industries, vol. 20, no. 4-6, pp. 375386, 2007.

[121] F. Alfert, "Cost comparison of dust explosion protection techniques available on the market," in Proceedings of the 2nd World Seminar on the Explosion Phenomenon and on the Application of Explosion Protection Techniques in Practice, EuropEx, Gent, Belgium, March 1996.

[122] H. Janssens, "Sicherheit zu einem erschwinglichen Preis!," VDI-Berichte, no. 1601, pp. 271-279, 2001. 

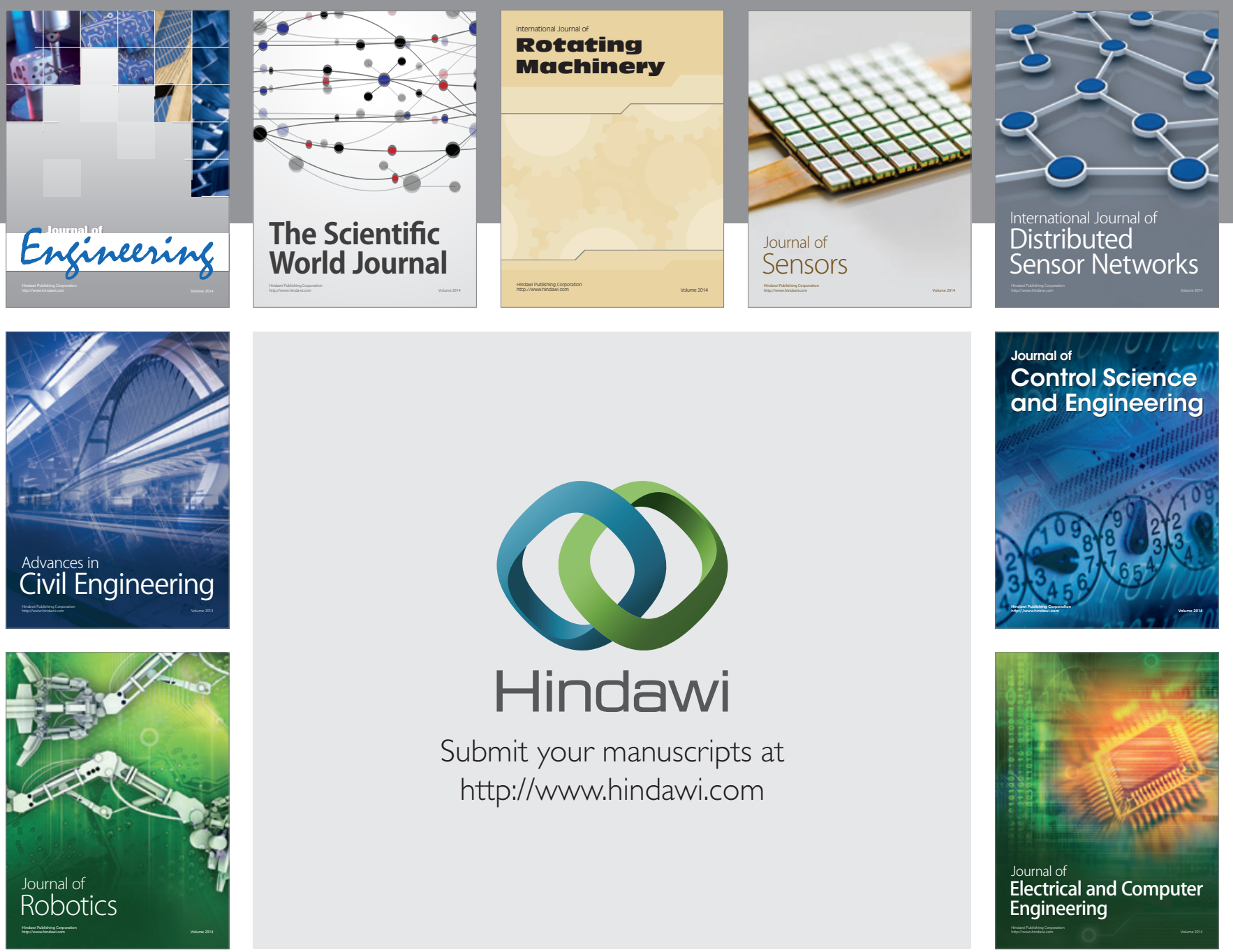

Submit your manuscripts at

http://www.hindawi.com
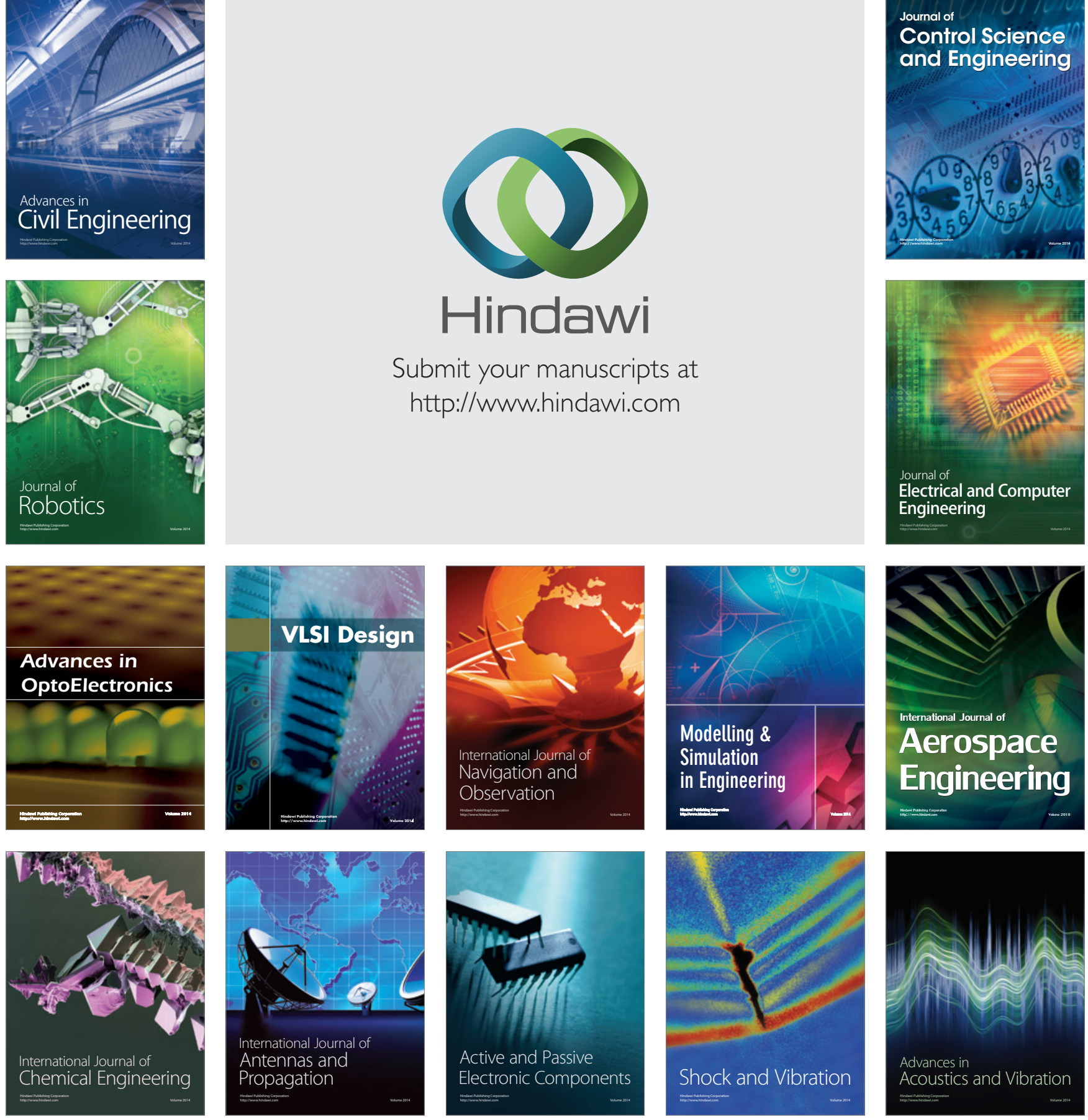